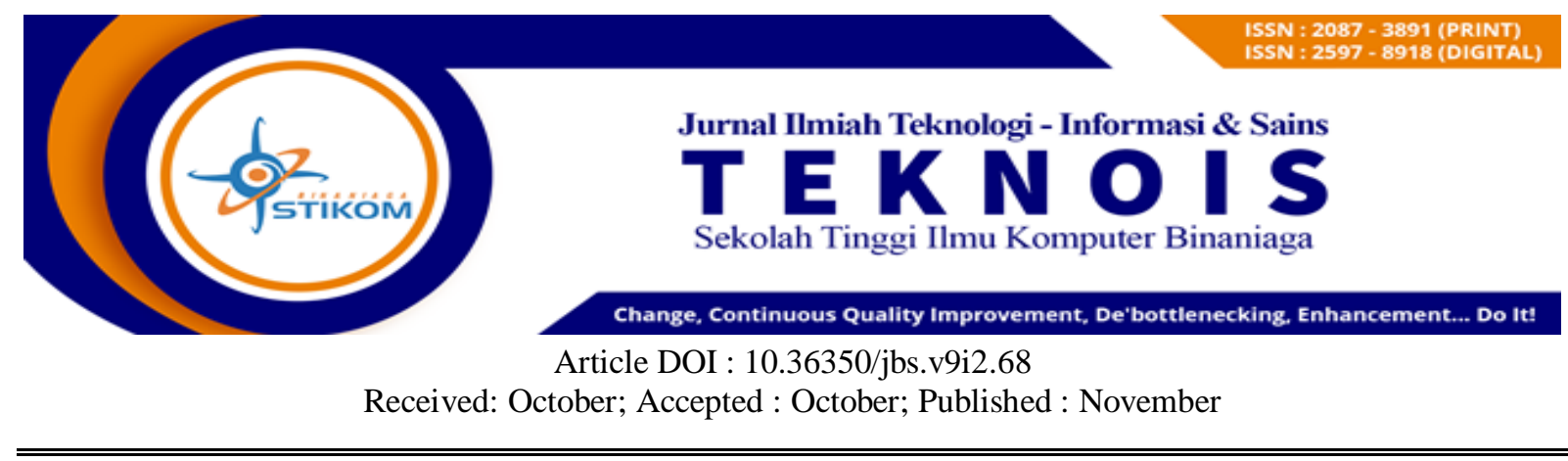

\title{
Sistem informasi nilai akademik mahasiswa menggunakan teknik json dan nfc
}

\author{
Arif Harbani $^{1^{*}}$, Ari Fajrianto ${ }^{2}$ \\ ${ }^{1}$ Teknik Informatika/STIKOM Binaniga \\ Email: arifharbani@gmail.com \\ ${ }^{2}$ Teknik Informatika/STIKOM Binaniga \\ Email: arifajrianto421@gmail.com
}

\begin{abstract}
Higher education as an institution engaged in the field of science can take advantage of technological developments. One of them is in terms of flexibility and efficiency of students in accessing the data they need related to academic activities in higher education such as student value information. This study aims to make it easy for students to be able to access value information easily. The development model used in this study is a prototype by making an application using NFC and JSON technology as a message format. This research was conducted at STIKOM Binaniaga Bogor with 60 students as samples of application trial subjects. The results of the analysis showed $85.63 \%$ of the level of appropriateness of the application, it shows with NFC technology and the application can facilitate students in getting information on student academic values.
\end{abstract}

Keywords: Near Field Communication (NFC); JSON.

\begin{abstract}
ABSTRAK
Perguruan tinggi sebagai institusi yang bergerak dalam bidang keilmuan dapat memanfaatkan perkembangan teknologi. Salah satunya dalam hal fleksibilitas dan efisiensi mahasiswa dalam mengakses data yang mereka butuhkan terkait kegiatan akademik di perguruan tinggi seperti informasi nilai mahasiswa. Penelitian ini bertujuan untuk memberikan kemudahan kepada mahasiswa untuk dapat mengakses informasi nilai secara mudah. Model pengembangan yang digunakan dalam penelitian ini adalah prototype dengan membuat sebuah aplikasi menggunakan teknologi NFC dan JSON sebagai format pesan. Penelitian ini dilakukan di STIKOM Binaniaga Bogor dengan 60 mahasiswa sebagai sampel subjek uji coba aplikasi. Hasil analisa menunjukan 85,63\% dari tingkat kelayakan aplikasi, itu menunjukan dengan teknologi NFC dan aplikasi tersebut dapat mempermudah mahasiswa dalam mendapatkan informasi nilai akademik mahasiswa.
\end{abstract}

Keywords: Near Field Communication (NFC); JSON. 


\section{A. PENDAHULUAN}

\section{Latar Belakang}

Salah satu perangkat lunak yang sedang berkembang saat ini adalah teknologi pengiriman data pada handphone yaitu Near Field Communication (NFC). Sebelumnya, aplikasi pengiriman data pada handphone pertama kali muncul adalah Infrared, selanjutnya Bluetooth dan kini yang tengah berkembang adalah NFC. Kebutuhan pengiriman data yang lebih efisien dan memiliki banyak fungsi melatar belakangi hadirnya NFC. NFC adalah pengembangan dari teknologi Radio Frequency Identification (RFID) yang digunakan ke dalam perangkat handphone untuk memudahkan transaksi, contohnya transaksi perguruan tinggi.

Perguruan tinggi sebagai institusi dalam bidang keilmuan dapat memanfaatkan perkembangan teknologi. Salah satunya dalam hal fleksibilitas dan efisiensi mahasiswa dalam mengakses data yang dibutuhkan terkait kegiatan akademik seperti informasi nilai mahasiswa. Masih banyak perguruan tinggi yang menerapkan cara manual untuk mendapatkan informasi tersebut. Mahasiswa yang ingin mengakses informasi nilai harus datang ke kampus, atau mengakses situs perguruan tinggi dan mendapatkan informasi yang tidak valid. Sehingga perlu dikembangkan metode JSON (Java Script Object Notation) berbasis Desktop dengan teknologi NFC.

Penulisan format data menggunakan JSON sangatlah singkat karena menggunakan notasinotasi javascript seperti kurung siku dan kurung kurawal. NFC merupakan teknologi yang berkembang pada smartphone dan perangkat pendukung komputer. Dengan adanya JSON dan NFC dapat dijadikan media untuk mengembangkan sistem informasi nilai di perguruan tinggi sehingga informasi nilai dapat dilihat secara langsung dan diperoleh data terbaru.

\section{Permasalahan}

Dari uraian latar belakang diatas, maka dapat diidentifikasi masalah dalam penelitian ini adalah :

a. Lambatnya proses pengambilan informasi bila menggunakan barcode dan keyboard.

b. Proses informasi yang didapatkan tidak efisien karena harus masuk kedalam sistem absensi.

\section{Tujuan}

Adapun tujuan dari penelitian ini adalah :

a. Menerapkan metode JSON dan NFC untuk dapat memberikan informasi nilai akademik kepada mahasiswa STIKOM Binaniaga Bogor.

b. Memberikan kemudahan kepada mahasiswa untuk dapat mengakses informasi nilai

\section{B. METODE}

Metode yang digunakan adalah metode eksperimen, artinya bahwa penelitian yang dilakukan untuk melakukan uji coba terhadap permasalahan tertentu dengan penggunaan teori tertentu, didapatkan hasil yang tepat antara permasalahan dengan teori yang digunakan.

\section{Prosedur Pengembangan}

Langkah-langkah pengembangan (merujuk model pengembangan menggunakan Protoyping) sebagaimana ditunjukkan pada gambar 2 adalah sebagai berikut:

a. Analisa Kebutuhan Sistem

Sebagai bagian dari studi awal bertujuan mengidentifikasi masalah dan kebutuhan spesifik sistem, yaitu spesifikasi mengenai hal-hal yang akan dilakukan sistem ketika diimplementasikan. 
b. Desain Sistem

Dapat dipandang sebagai desain interface, data dan proses dengan tujuan menghasilkan spesifikasi yang sesuai dengan produk dan interface pemakai, struktur database serta pemrosesan dan prosedur.

\section{c. Development}

Pada tahap ini dibangun aplikasi NFC menggunakan PHP sebagai bahasa pemrograman dan terintegrasi dengan database perguruan tinggi melalui RESTful API sebagai middleware dan JSON sebagai format pesan.

d. Pengujian Sistem

Pengujian pada tahap ini dilakukan untuk mengetahui tingkat keberhasilan dan kesalahan sistem dalam melakukan tugasnya.

e. Implementasi

Aplikasi setelah diujicobakan kemudian diterapkan dan dilihat dampaknya setelah digunakan.

\section{Uji Coba Produk}

a) Desain Uji Coba

1) Uji Coba Ahli Sistem Informasi

Pengujian kepada ahli sistem informasi untuk mereview produk awal sistem yang dilakukan dengan menyebarkan angket.

2) Uji Coba Pengguna

Dilakukan untuk mengetahui kelayakan dan ketepatan informasi yang dihasilkan dengan menyebarkan angket kepada mahasiswa STIKOM Binaniaga Bogor sebagai pengguna.

b) Subjek Uji Coba

Subjek uji coba yaitu ahli sistem informasi sebanyak 1 orang dan uji coba kelompok, yaitu mahasiswa aktif angkatan 2015/2016 STIKOM Binaniaga Bogor sebanyak 60 orang. Sampel uji coba ini berdasarkan hasil perhitungan menggunakan rumus Slovin (Riduwan, 2005:65) yaitu : $\mathrm{n}=\mathrm{N} / \mathrm{N}(\mathrm{d})^{2}+1$ (Ket.: $\mathrm{n}=$ Sampel; $\mathrm{N}=$ Populasi; $\mathrm{d}=$ Nilai presisi $95 \%$ atau sig. $=0,05)$. Jumlah seluruh mahasiswa 71 orang, jadi $=71 / 71(0.05)^{2}+1=60,297$ (dibulatkan menjadi 60 orang).

\section{Jenis Data}

\section{a) Jenis Data Ahli}

Data dari ahli adalah data yang berhubungan dengan teknis pengembangan suatu alat dan aplikasi yang dapat dinilai dari segi usability, fungtionality, dan komunikasi visual.

b) Jenis Data Pengguna

Data dari pengguna adalah berupa kualitas produk ditinjau dari kesesuaian, keakuratan, kecepatan sistem dalam penggunannnya dan fungsi-fungsi sistem secara keseluruhan.

\section{Instrumen Pengumpulan Data}

Menurut Sugiyono (2013), instrumen penelitian adalah alat ukur dalam penelitian. Adapun instrumen yang digunakan dalam penelitian pengembangan ini yaitu angket/kuesioner. 
Volume 9 Number 2 November 2019 Page. 79-90

Journal Homepage : http://teknois.stikombinaniaga.ac.id/index.php/JBS

DOI Link : http://doi.org/10.36350/jbs.v9i2

Tabel 1. Kisi-kisi Instrumen untuk Ahli Sistem Informasi

\begin{tabular}{|c|l|l|c|}
\hline No & \multicolumn{1}{|c|}{ Aspek Penilaian } & \multicolumn{1}{|c|}{ Indikator } & Jumlah Butir \\
\hline 1 & \multirow{2}{*}{ Komponen Input } & User Interface & 1 \\
\cline { 3 - 4 } & & Interaksi Sistem & 1 \\
\hline 2 & \multirow{2}{*}{ Komponen Model } & Prosedur Sistem & 1 \\
\cline { 3 - 4 } & & Logika Program & 1 \\
\hline 3 & \multirow{2}{*}{ Komponen Output } & Ketepatan Informasi & 1 \\
\cline { 3 - 4 } & & Kekinian Informasi & 1 \\
\hline 4 & \multirow{2}{*}{ Komponen Teknologi } & Waktu Respon & 1 \\
\cline { 3 - 4 } & & Keluwesan Sistem (Sistem Flexibility) & 1 \\
\hline 5 & Komponen Control & Keamanan Sistem & \\
\hline 6 & Arsitektur Data & Isi-isi Basis Data (Database Contents) & 1 \\
\hline
\end{tabular}

Tabel 2. Kisi-Kisi instrumen untuk pengguna

\begin{tabular}{|c|c|c|c|}
\hline No. & Aspek Penilaian & Indikator & Jumlah Butir \\
\hline \multirow[t]{4}{*}{1} & \multirow[t]{4}{*}{ Kualitas Informasi } & Kelengkapan (Completeness) & 1 \\
\hline & & Keseksamaan(Precision) & 1 \\
\hline & & Reabilitas(Reability) & 1 \\
\hline & & Keluaran(Format of Output) & 1 \\
\hline \multirow{6}{*}{2} & \multirow{6}{*}{ Kualitas Sistem } & Fleksibilitas Sistem (SystemFlexibility) & 1 \\
\hline & & Integrasi Sistem (System Integration) & 1 \\
\hline & & Waktu Untuk Merespon (Time toRespon) & 1 \\
\hline & & Pemulihan Kesalahan (ErrorRecovery) & 1 \\
\hline & & kses (Convinience of access) & 1 \\
\hline & & Bahasa (Language) & 1 \\
\hline \multirow{3}{*}{3} & \multirow{3}{*}{ Kualitas Layanan } & Jaminan (Assurance) & 1 \\
\hline & & Empati ( Emphaty) & 1 \\
\hline & & Tanggapan (Responsiveness) & 1 \\
\hline \multirow[t]{2}{*}{4} & \multirow[t]{2}{*}{ Penggunaan } & Waktu Penggunaan Harian (DailyUse Time) & 1 \\
\hline & & Frekuensi Penggunaan (Frequency of Use) & 1 \\
\hline \multirow[t]{2}{*}{5} & \multirow[t]{2}{*}{ Kepuasaan Pengguna } & Pembelian Ulang (Repeat Purchase) & 1 \\
\hline & & Pengunjung Ulang (Repeat Visit) & 1 \\
\hline \multirow[t]{3}{*}{6} & \multirow[t]{3}{*}{ Keuntungan Bersih } & $\begin{array}{l}\text { Kecepatan Menyelesaikan Tugas (Speed of Acomplishing } \\
\text { Task) }\end{array}$ & 1 \\
\hline & & Kinerja Pekerjaan (Job Peformace) & 1 \\
\hline & & Efektivitas (Efectiveness) & 1 \\
\hline
\end{tabular}

Teknik pengolahan data pada penelitian pengembangan ini menggunakan pengukuran skala likert. Tingkat persetujuan yang dimaksud dalam skala Likert ini terdiri dari 5 pilihan skala yang mempunyai gradasi dari Sangat Setuju (SS) hingga Sangat Tidak Setuju (STS).

\section{Kalibrasi Instrumen}

a) Uji Validitas Instrumen Angket

Menurut Arikunto (2005:65), validitas adalah suatu ukuran yang menunjukkan tingkat kesahihan suatu tes. Suatu tes dikatakan valid apabila tes tersebut mengukur apa yang hendak diukur. Tes memiliki validitas yang tinggi jika hasilnya sesuai dengan kriteria, dalam arti memiliki kesejajaran antara tes dan kriteria. Pengujian dilakukan per item dengan rumus korelasi product moment (Arikunto, 2005:170). Butir soal dikatakan valid, jika $\mathrm{r}$ hitung $\geq \mathrm{r}$ tabel product moment dengan taraf signifikansi $5 \%$.

b) Uji Reliabilitas Instrumen Angket

Pengertian reliabilitas menurut Sugiyono (2013) adalah serangkaian pengukuran atau serangkaian alat ukur yang memiliki konsistensi jika pengukuran yang dilakukan dengan alat ukur itu dilakukan secara berulang. Menurut Johnson and Christensen (2012) bahwa apabila koefisien alpha Cronbach $\geq 0,7$, maka instrumen dikatakan reliabel.

(C2019 Teknois : Jurnal IImiah Teknologi Informasi dan Sains. Copyrights All rights reserved 


\section{Teknik Analisa Data}

Data hasil penilaian kelayakan dianalisis dengan teknik analisis deskriptif, sebagai berikut:

$$
\text { Presentase }=\frac{\sum \text { (jawaban } X \text { bobot tiap pilihan) }}{n X \text { bobot tertinggi }}
$$

Keterangan: $\quad \sum=$ Jumlah; $\mathrm{N}=$ Jumlah seluruh item

Tabel 3. Konversi Tingkat Pencapaian

\begin{tabular}{|c|c|}
\hline Tingkat Ketercapaian & Kualifikasi \\
\hline $90 \%-100 \%$ & Sangat Layak \\
\hline $75 \%-89 \%$ & Layak \\
\hline $65 \%-74 \%$ & Cukup Layak \\
\hline $55 \%-64 \%$ & Kurang Layak \\
\hline $0 \%-54 \%$ & Tidak Layak \\
\hline
\end{tabular}

\section{HASIL DAN PEMBAHASAN}

\section{Hasil}

a. Pengumpulan Kebutuhan

Merupakan kegiatan yang dilakukan dalam rangka mengumpulkan kebutuhan-kebutuhan dalam pengembangan sistem dengan teknik pengumpulan data sebagai berikut :

1) Pengumpulan Dokumen

Pengumpulan dokumen dilakukan untuk memenuhi kebutuhan dalam mengidentifikasi sebuah sistem, dokumen-dokumen tersebut berasal dari bagian administrasi data mahasiswa.

2) Wawancara

Dilakukan kepada staff administrasi data mahasiswa dalam rangka mempelajari bagaimana proses transaksi informasi nilai mahasiswa. Sistem yang berjalan saat ini ialah sebagai berikut:

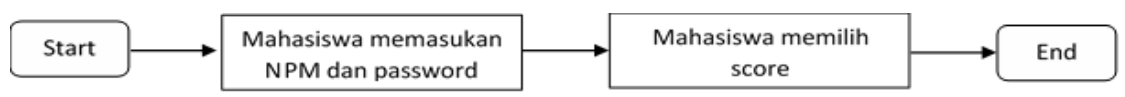

Gambar 1. Proses Bisnis Lama

Pada gambar 1 merupakan proses transaksi diawali dengan mahasiswa memasukan NPM dan password kedalam sistem absensi pada komputer yang telah disediakan oleh kampus, setelah login mahasiswa memilih menu score untuk melihat nilai. Nilai dapat dilihat sejak awal perkuliahan hingga yang paling baru.

3) Perancangan

Perancangan merupakan proses perencanaan, pembuatan dan penggambaran dari sistem yang akan dikembangkan. Dalam proses perancangan dibuatlah skenario yang dapat digunakan untuk mengidentifikasi kebutuhan sistem. Skenario-skenario ini, sering dinamakan sebagai use case yang menyediakan deskripsi rinci tentang bagaimana sistem digunakan (Pressman, 2012:159).

a) Proses Bisnis

Suatu kumpulan dari aktivitas (task) atau pekerjaan terstruktur yang saling berhubungan untuk menyelesaikan suatu masalah tertentu atau yang menghasilkan suatu keluaran (produk/output) atau layanan (demi meraih tujuan tertentu) dan mendukung pencapaian tujuan serta sasaran strategis dari suatu organisasi.

Suatu proses bisnis yang baik harus mempunyai tujuan mengefektifkan, mengefisiensikan dan meningkatkan produktifitas dari suatu organisasi. Berikut 
adalah gambaran proses bisnis untuk aplikasi informasi nilai akademik dengan menerapkan teknologi NFC (Near Field Communication) dapat dilihat pada gambar berikut:

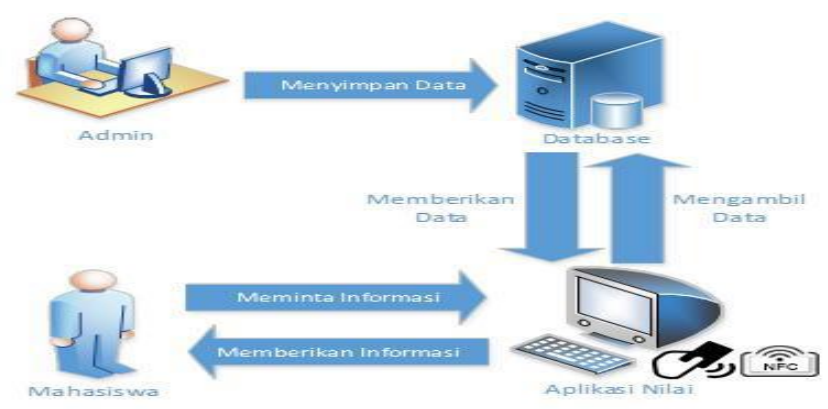

Gambar 2. Proses Bisnis Baru

Gambar 2 merupakan proses bisnis baru, diawali dengan Administrator menyimpan nilai mahasiswa ke database, kemudian mahasiswa menempelkan kartu ke perangkat NFC yang telah dipasang pada komputer, lalu aplikasi akan mengambil data nilai yang telah tersimpan pada database dan menampilkannya.

b) Use case Diagram

Use case ialah diagram untuk menujukan peran dari berbagai pengguna dan bagaimana peran-peran menggunakan sistem (Satzinger, Jackson dan Burd, 2010, p242). Use case diagram digunakan untuk memodelkan bisnis proses berdasarkan perspektif pengguna sistem, use case diagram terdiri atas diagram untuk use case dan aktor. Aktor merupakan sejumlah orang (atau sarana) yang berbeda yang menggunakan sistem atau produk di dalam konteks fungsi-fungsi dan perilakuperilaku yang harus dideskripsikan selanjutnya (Pressman, 2012:160). Aktor dalam sistem perangkat lunak yang akan dikembangkan dinamakan sebagai user yaitu pengguna dari sistem, dan aktivitas-aktivitas yang mungkin dapat dilakukan aktor di dalam sistem digambarkan dalam bentuk sejumlah use case. Aplikasi yang dikembangkan memiliki dua aktor yaitu, Administrator dan Mahasiswa.

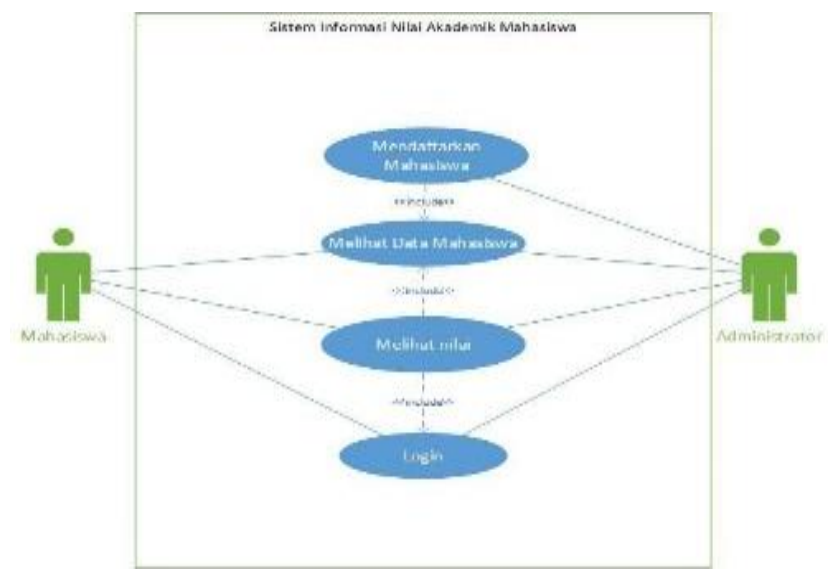

Gambar 3. Usecase Diagram

Gambar 3 menjelaskan bahwa yang menjadi aktor ialah mahasiswa dan administrator, kedua aktor memiliki hak akses yang sama, namun hanya admin yang dapat mendaftarkan mahasiswa. Para aktor diharuskan untuk login terlebih dahulu untuk dapat mengakses kedalam aplikasi.

c) Arsitektur Antar Tabel

Arsitektur antar tabel diagram mendeskripsikan jenis-jenis objek dalam sistem dan

berbagai macam hubungan statis yang terdapat di antara mereka. Arsitektur antar (C2019 Teknois : Jurnal Ilmiah Teknologi Informasi dan Sains. Copyrights All rights reserved 
tabel juga menunjukan properti dan operasi sebuah tabel dan batasan-batasan yang terdapat dalam hubungan objek tersebut.

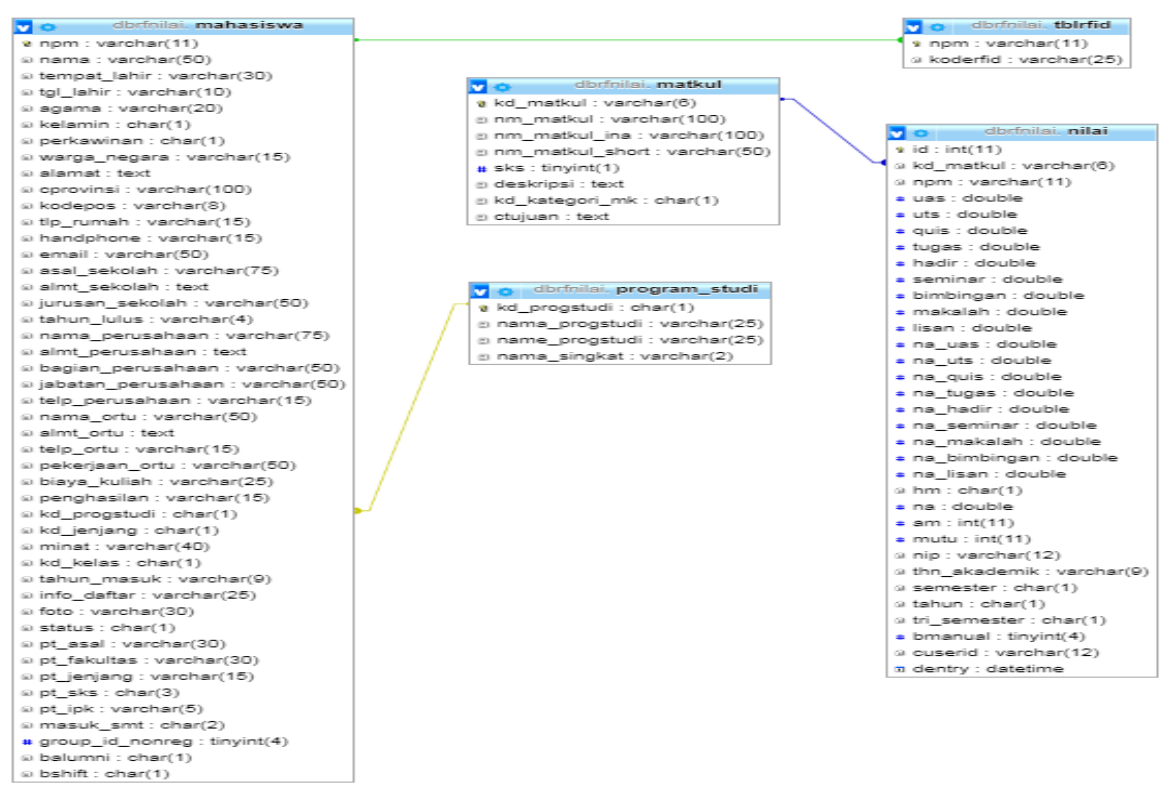

Gambar 4. Hubungan antar tabel

Pada gambar 4 menjelaskan bahwa aplikasi informasi nilai akademik memiliki 3 bagian tampilan yaitu, tampilan login, tampilan admin dan tampilan nilai. Proses dimulai dengan tampilan login admin, admin akan mendaftarkan NPM dan kode RFID mahasiswa dan menyimpannya kedalam tabel "tblrfid". Kemudian mahasiswa akan login menggunakan kartu RFID yang telah terdaftar, dan sistem akan mencocokkan NPMnya dengan tabel mahasiswa. Setelah berhasil data akan ditampilkan dari tabel nilai berupa kode matakuliah, nama matakuliah dan nilai yang diperoleh oleh mahasiswa tersebut.

d) Deployment Diagram

Berdasarkan gambar 7. dapat diketahui bahwa struktur computer server terdiri dari XAMPP dan MySQL. Aplikasi informasi nilai berada pada komputer admin dan mahasiswa. Admin dan mahasiswa yang menggunakan personal computer dan menggunakan perangkat card reader NFC untuk dapat membaca kartu RFID. Proses login disini memanfaatkan teknologi NFC sebagai pengganti username dan password. Mahasiswa hanya perlu membuka aplikasi nilai tersebut dan menempelkan kartu pada perangkat NFC. Setelah berhasil login, akan disajikan informasi nilai akademik mahasiswa.
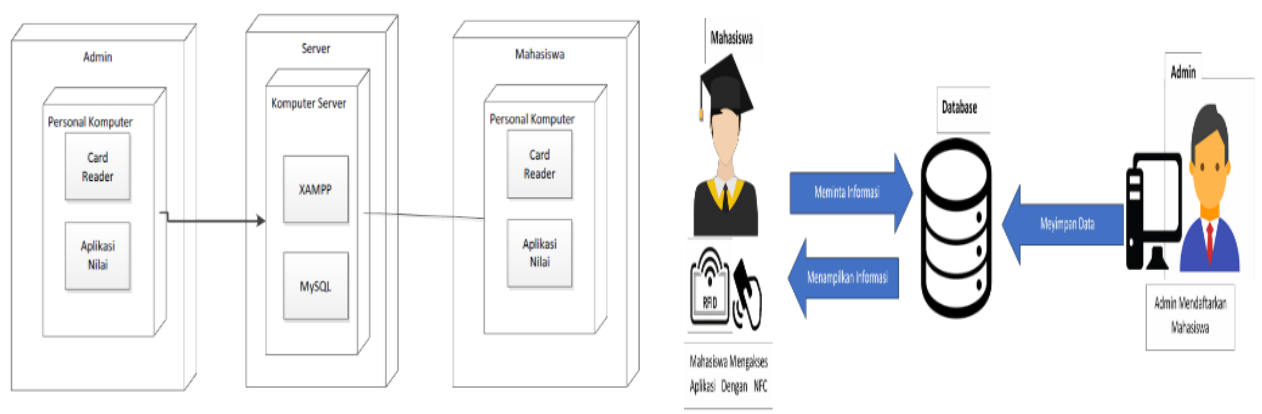

Gambar 5. Deployment Diagram

Gambar 6. Skema Informasi Nilai Akademik 
b. Membangun Prototyping

Membangun prototyping disini berfokus pada proses membangun skema pemberian informasi nilai. Berikut ini merupakan contoh gambar skema yang akan berjalan.

Gambar 6 mendefinisikan penerapan NFC pada penelitian ini, bertujuan untuk memudahkan pengguna dalam mengakses sebuah informasi nilai. Dengan menggunakan NFC mahasiswa tidak perlu lagi untuk masuk kedalam sistem absensi, cukup dengan mengakses aplikasi dengan bantuan sebuah kartu.

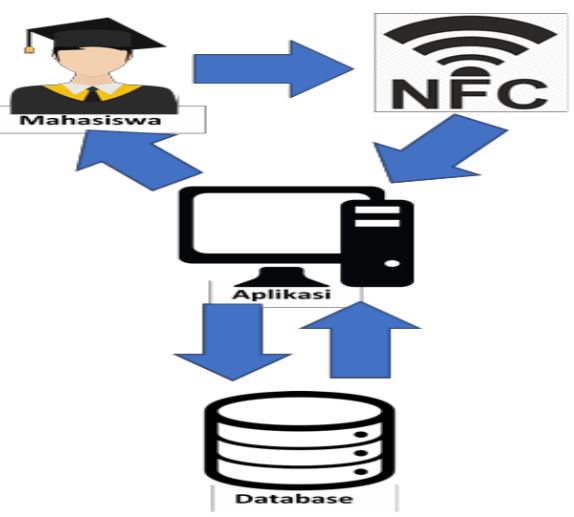

Gambar 7. Skema penerapan JSON dan NFC

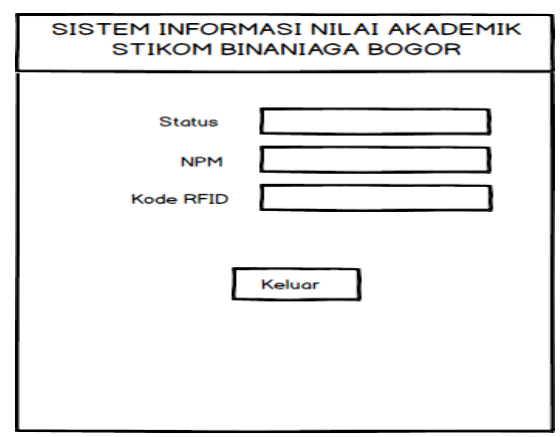

Gambar 8. Desain tampilan form input login

Gambar 7 adalah alur penerapan Teknologi NFC dan JSON. Dimulai dari mahasiswa mengakses aplikasi melalui perangkat NFC dengan menempelkan kartu. Perangkat NFC reader membaca kode pada kartu untuk divalidasi dengan kode yang sudah didaftarkan oleh admin. Aplikasi akan meminta data dalam format JSON ke database. Database memberikan data nilai mahasiswa sesuai dengan permintaan. Aplikasi akan menampilkan informasi nilai matakuliah mahasiswa tersebut.

Admin akan mendaftarkan mahasiswa yang akan menggunakan aplikasi (gambar 8). Untuk menambahkan mahasiswa baru, admin akan memilih "baru" pada bagian status dan memasukan NPM dan kode RFID mahasiswa. Jika merubah data maka admin akan memilih "Mengganti” untuk merubah kode RFID yang sudah terdaftar sebelumnya dengan yang baru dan data akan tersimpan dalam database. Setelah mahasiswa terdaftar adalah interface dan mahasiswa dapat login ke dalam aplikasi dengan kartu RFID yang dimiliki.

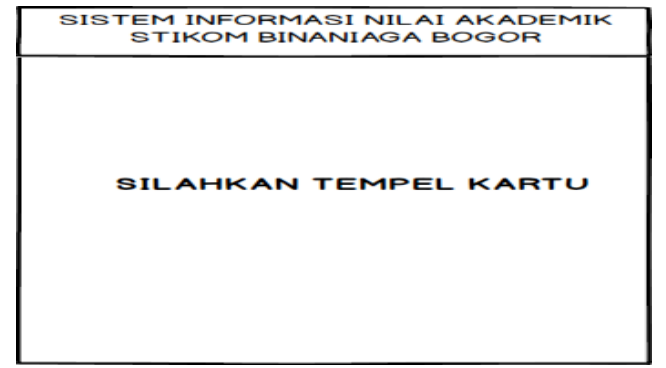

Gambar 9. Desain tampilan Login

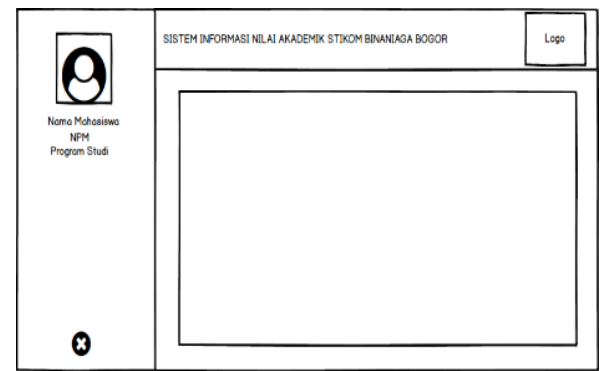

Gambar. 10. Desain tampilan informasi nilai

Gambar 9 menampilkan interface untuk mahasiswa agar dapat mengakses dengan menempelkan katu ke perangkat card reader NFC. Jika kode RFID sesuai maka akan dialihkan ke tampilan berisi informasi nilai mahasiswa. Desain login tersebut juga digunakan admin untuk masuk kedalam form pendaftaran mahasiswa dengan menekan tombol "Ctrl + A" maka admin langsung diarahkan ke form pendaftaran mahasiswa.

Pada gambar 10, nilai mahasiswa akan ditampilkan dalam bentuk tabel yang terdiri dari: Kode matakuliah, Nama matakuliah, dan Nilai, juga ditampilkan foto, nama mahasiswa, NPM, dan program studi dari mahasiswa tersebut. Jika telah selesai maka mahasiswa dapat keluar atau kembali ke menu login sebelumnya dengan memilih tombol silang (X) 
Gambar 15 merupakan pengkodean yang akan menyajikan informasi nilai akademik dalam bentuk tabel yang terdiri dari nomer, kode matakuliah, nama matakuliah, dan nilai. Nilai yang ditampilkan adalah nilai permatakuliah dari semester awal sampai yang terbaru.

d. Implementasi

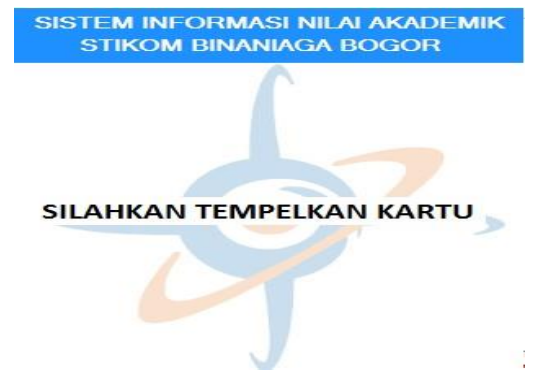

Gambar 17. Interface Halaman Utama

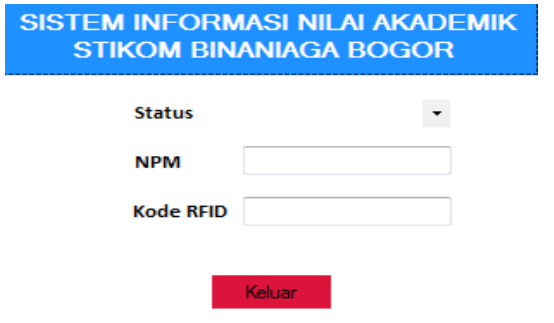

Gambar 18. Interface pendaftaran kode RFID

Pada gambar 17 menampilkan interface awal untuk mahasiswa yang akan menempelkan kartu untuk melihat informasi nilai.

Gambar 18 menampilkan interface administrator untuk mendaftarkan kartu RFID. Admin akan diminta untuk meilih status antara membuat baru atau mengganti dan juga memasukkan NPM mahasiswa dan kode RFID. Kemudian ada tombol keluar untuk kembali ke interface awal.

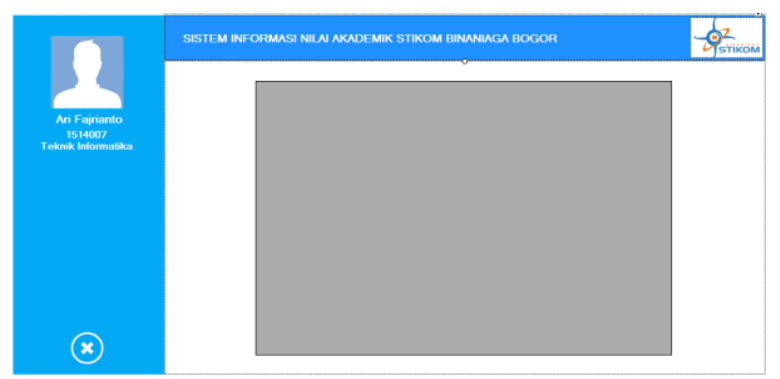

Gambar 19. Interface Informasi Nilai

Pada gambar 19 akan ditampilkan nilai mahasiswa pada kolom grid. Dan juga akan ditampilkan foto, nama mahasiswa, NPM, dan program studi mahasiswa tersebut.

\section{e. Uji Coba Sistem}

Uji coba sistem ini dilakukan oleh Ahli Sistem Informasi apakah aplikasi yang sudah di bangun sudah sesuai dengan keinginan pengguna atau belum. Uji coba yang dilakukan pada tahap ini adalah dengan cara menguji aplikasi yang sudah dibuat dan penilaiannya juga dilakukan dengan menggunakan metode penyebaran kuesioener kepada para responden.

\section{1) Kuesioner Untuk Ahli Sistem Informasi}

Tabel 4. Kuesioner Ahli Sistem Informasi

\begin{tabular}{|c|l|l|c|c|}
\hline \multirow{2}{*}{ No. } & \multicolumn{1}{|c|}{ Aktivitas } & \multicolumn{1}{c|}{ Hasil Yang Diharapkan } & \multicolumn{1}{c|}{ Taraf } \\
\cline { 3 - 5 } & & & \multicolumn{1}{|c|}{ Ya } & Tidak \\
\hline 1 & User Interface & Menampilkan halaman utama & & \\
\hline 2 & Interaksi Sistem & Tampil halaman pendaftaran kode NFC & & \\
\hline 3 & Prosedur Program & User dapat melihat halaman informasi nilai mahasiswa & & \\
\hline 4 & Logika Program & Ketika kartu ditempelkan user dapat melihat informasi nilai yang & & \\
\hline 5 & Ketepatan & User mendapatkan informasi sesuai dengan nilai yang diperoleh & & \\
\hline 6 & Kekinian & Setelah kartu ditempel informasi nilai dapat langsung dilihat oleh & & \\
\hline 7 & Waktu Respon & Membutuhkan waktu yang cepat dalam proses login menggunakan & & \\
\hline
\end{tabular}




\begin{tabular}{|c|l|l|l|l|}
\hline 8 & Keluwesan System & Menu-menu berfungsi dengan baik & & \\
\hline 9 & Keamanan Sistem & System memiliki keamanan yang memadai & & \\
\hline 10 & Arsitektur Data & Database terintegrasi dengan baik & & \\
\hline
\end{tabular}

2) Kuesioner Untuk Pengguna

Tabel 5. Kuesioner Pengguna

\begin{tabular}{|c|c|c|c|c|c|c|}
\hline \multirow{2}{*}{ No. } & \multirow{2}{*}{ Pertanyaan } & \multicolumn{5}{|c|}{ Pilihan } \\
\hline & & SS & $\mathbf{S}$ & RG & TS & STS \\
\hline \multicolumn{7}{|c|}{ Kualitas Informasi } \\
\hline 1 & Memberikan informasi yang lengkap mengenai nilai? & & & & & \\
\hline 2 & Memberikan informasi yang dapat dipercaya? & & & & & \\
\hline 3 & Menampilkan Informasi yang akurat? & & & & & \\
\hline 4 & Menampilkan informasi nilai yang mudah dimengerti? & & & & & \\
\hline \multicolumn{7}{|c|}{ Kualitas Sistem } \\
\hline 5 & $\begin{array}{l}\text { Apakah setiap fitur berfungsi sesuai dengan fungsi masing - } \\
\text { masing? }\end{array}$ & & & & & \\
\hline 6 & Apakah aplikasi mudah untuk digunakan? & & & & & \\
\hline 7 & Apakah setiap proses membutuhkan waktu yang singkat? & & & & & \\
\hline 8 & $\begin{array}{l}\text { Apakah tidak terjadi eror/kesalahan dalam menjalankan } \\
\text { aplikasi? }\end{array}$ & & & & & \\
\hline 9 & Apakah aplikasi nyaman untuk digunakan? & & & & & \\
\hline 10 & $\begin{array}{l}\text { Apakah bahasa yang digunakan dalam aplikasi mudah } \\
\text { dipahami? }\end{array}$ & & & & & \\
\hline \multicolumn{7}{|c|}{ Kualitas Layanan } \\
\hline \multicolumn{7}{|c|}{\begin{tabular}{l|l}
11 & Apakah dengan menggunakan NFC informasi data pribadi \\
anda dapat terjamin aman?
\end{tabular}} \\
\hline \multicolumn{7}{|c|}{12 Apakah aplikasi memberikan informasi yang anda butuhkan? } \\
\hline \multicolumn{7}{|c|}{$13 \begin{array}{l}\text { Apakah dengan NFC dapat } \\
\text { memnermudah untuk mengakses informasi nilai? }\end{array}$} \\
\hline \multicolumn{7}{|c|}{ Penggunaan } \\
\hline \multicolumn{7}{|c|}{ 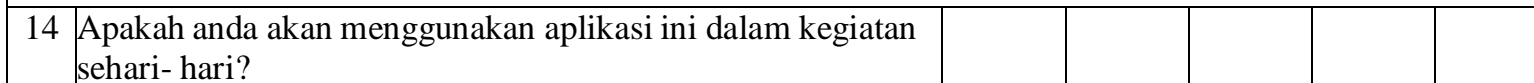 } \\
\hline \multicolumn{7}{|c|}{\begin{tabular}{l|l}
15 & Apakah aplikasi ini dapat digunakan dalam jangka waktu \\
yang panjang?
\end{tabular}} \\
\hline \multicolumn{7}{|c|}{ Kepuasaan Pengguna } \\
\hline \multicolumn{7}{|c|}{\begin{tabular}{|l|l|}
16 & Apakah anda akan terus menggunakan aplikasi ini? \\
\end{tabular}} \\
\hline \multicolumn{7}{|c|}{\begin{tabular}{|l|l|}
17 & Apakah anda puas dengan aplikasi ini? \\
\end{tabular}} \\
\hline \multicolumn{7}{|c|}{ Keuntungan Bersih } \\
\hline 18 & Apakah setiap proses membutuhkan waktu yang singkat? & & & & & \\
\hline 19 & $\begin{array}{l}\text { Apakah Aplikasi memudahkan anda dalam mendapatkan } \\
\text { informasi nilai? }\end{array}$ & & & & & \\
\hline 20 & Apakah proses melihat nilai menjadi lebih efektif? & & & & & \\
\hline
\end{tabular}

\section{Pembahasan}

Data yang diperoleh melalui instrumen penelitian diuji dengan menggunakan statistik deskriptif kuantitatif untuk menggambarkan karakteristik data masing-masing variabel. Hasilnya digunakan sebagai jawaban atas kelayakan aspek-aspek yang diteliti. Presentase kelayakan disajikan pada tabel 6 di bawah ini.

Tabel 6. Presentase kelayakan

\begin{tabular}{|l|c|c|c|}
\hline \multicolumn{1}{|c|}{ Aspek penilaian } & Skor yang Diobservasi & Skor yang diharapkan & Persentase \\
\hline Kualitas Informasi & 1.045 & 1.200 & $87,08 \%$ \\
\hline Kualitas Sistem & 1.543 & 1.800 & $85,72 \%$ \\
\hline Kualitas Layanan & 769 & 900 & $85,44 \%$ \\
\hline
\end{tabular}




\begin{tabular}{|l|c|c|c|}
\hline Penggunaan & 520 & 600 & $86,66 \%$ \\
\hline Kepuasaan Pengguna & 495 & 600 & $82,5 \%$ \\
\hline Keuntungan Bersih & 766 & 900 & $85,11 \%$ \\
\hline Total & 5.138 & 6.000 & $85,63 \%$ \\
\hline
\end{tabular}

Persentase yang didapat sebesar 85,63\%, maka dapat dikategorikan “layak".

\section{KESIMPULAN}

Berdasarkan hasil penelitian dapat diambil kesimpulan yaitu dengan memanfaatkan NFC (Near Field Communicattion) mahasiswa dapat dengan mudah untuk mengakses informasi nilai dengan lebih mudah.

\section{E. DAFTAR PUSTAKA}

[1] Johson, B. and Christensen, L. (2012), Educational Research Quantitave, Qualitative, and Mixed Approaches. London: SAGE Publications, Inc.

[2] Pressman, R. S. (2012). Rekayasa Perangkat Lunak Pendekatan Praktisi. Edisi 7. Yogyakarta: ANDI.

[3] Riduwan. (2005). Skala Pengukuran Variabel Penelitian. Bandung: Alfabeta.

[4] Satzinger, Jackson, Burd. 2010. System Analisis and Design with the Unified Process. USA: Course Technology, Cengage Learning

[5] Sudjana, Nana. 2005. Dasar-dasar Proses\Belajar Mengajar. Bandung: Sinar Baru Algensindo.

[6] Sugiyono (2013). Statistika untuk Penelitian, Bandung: Alfabeta

[7] Suharsimi, Arikunto. 2005. Manajemen Penelitian. Edisi Revisi. Jakarta: Rineka Cipta. 